\title{
Effect of Micro Insurance by Microfinance Institutions on Women Empowerment: A Case of Nakuru CBD, West Sub County, Kenya
}

\author{
Prof Clifford Machogu ${ }^{1 *} \quad$ Sharon Mwalasha ${ }^{2}$ \\ 1.School of Business and Economics, Methodist University, Nairobi ,Kenya \\ 2.School of Business and Economics, Kabarak University, P.O.Box 20157,Kabarak,Nakuru,Kenya
}

\begin{abstract}
The evolution of microfinance institutions in Kenya is seen as a catalyst for promoting women empowerment. One of the services provided by microfinance institutions is the micro insurance. Micro insurance refers to low premium, low coverage insurance services provided to low income clients excluded from commercial insurance schemes. In Kenya, already some insurance and non insurance institutions have welcomed micro insurance by introducing products such as Afya Bora by CIC and Salama Sure by UAP with Faulu Kenya offering Faulu Afya. Most of these products focus on primary risks such as Livestock and Crop, Health, Funeral and Life insurance. Scarce studies have devoted to the topic as many have relied to micro credit as overall microfinance institutions services here in Kenya. Hence the study sought to assess the effect of micro insurance by microfinance institutions on women empowerment in Nakuru CBD, West Sub County, Kenya. The study was guided by an objective namely to assess the effect of micro insurance by microfinance institutions in Nakuru CBD, West Sub County, Kenya. This study adopted the descriptive research. A sample of 127 respondents were selected from a population of 293 using simple random technique. The study adopted the use of a questionnaire as the primary data collection instrument that was constructed on a five point Likert scale. The data collected was analyzed using Statistical Package for Social Sciences (SPSS) and tools such as frequencies, percentages and Chi Square test of good fit were used. Inferential statistical analysis was done by use of Pearson's Correlation Coefficient to establish the relationship between the dependent and independent variables. Analyzed data was presented inform of statistical tables. Results show that micro insurance is statistically insignificant and negatively affect women empowerment. This study concludes that penetration of micro insurance services should be able to reach women. Some of the recommendations made included; the need to a further study to distinctively identify the effect of micro insurance by MFIs in group lending on women empowerment, further understanding the effects of new areas of microfinance such as that of micro-insurance services to help design better products, gain a competitive edge and stimulate the market in the long term for sustainable development.
\end{abstract}

Keywords: Micro insurance, Women Empowerment

DOI: $10.7176 /$ RJFA/11-18-08

Publication date:September $30^{\text {th }} 2020$

\section{Introduction \\ 1.1 Background of the study}

There are nearly three billion people living on less than \$2 per day globally (Hui, 2013). When financial shocks strikes, such as the death of a bread winner or costly health issues, the majority of them have no means of getting by. According to the International Association of Insurance Supervisors (IAIS), micro insurance means "Insurance that is accessed by or accessible to the low income population, potentially provided by a variety of different providers and managed in accordance with the generally accepted insurance practices". Micro insurance includes delivery of insurance products to the participants at the base of the pyramid to shield them from definite perils in consideration for premiums matching the possibility of occurrence of the risk (Makove, 2011). Beforehand, micro insurance was an obscure and unproven concept, with the landscape largely characterized by donor funded pilots or corporate social responsibility initiatives from a few pioneering companies (Churchill and Merry, 2014). The use of insurance is one of the risk mitigation measures that can alleviate the vulnerability of the poor households by replacing the uncertain prospect of large losses with the certainty of making small regular premium payments (Brown and Churchil, 1999). Most financial institutions, insurance included do not have strategies that are focused on bottom of the pyramid or the lower income groups or small and medium enterprises (Prahalad, 2010). They have instead focused mainly on the ready market of middle and high income bracket. The cumulative result of this neglect over the years is underserved low-end market and a stagnant insurance penetration ratio. Many low income people are insurable since they have assets to protect, however majority don't have insurance as they are unfamiliar with the concept of insurance as a risk management tool or put simply they lack awareness of insurance products or services. According to a research conducted by the German Institute for Economic Research in 2009, creating awareness among the customers was identified as a potential challenge to the development of insurance sector. The study found out that the demand for insurance is correlated to the customer perceptions of the end benefits of the products. Kamau (2013) also notes the contribution consumer education plays towards insurance. According to Morelli (2010), for insurance schemes to succeed, it must satisfy among other conditions comprehensibility and 
understandability by the clients. The level of income is also a key factor in insurance uptake. Dalal and Morduch (2010), state that one of the key challenge in the provision of Micro insurance is the target market that consist largely of the informal sector workers and self-employed with unpredictable and low incomes who are mostly women. This means that premiums will be small and in high frequency, which has a direct implication on per unit transaction cost. Insurers are often constrained by lack of low cost distribution channels that can reach the low income target market (Njuguna and Arunga, 2013). What differentiates micro insurance from other insurance is how it is made accessible to the low end market. Micro insurance products are generally distributed through microfinance institutions, post offices, churches and non-governmental organizations. Given the numerous small policies, administration of premiums and claims can be cumbersome and uneconomical. There are product design risks in the context of micro insurance because potential clients are exposed to a myriad of risks, all of which cannot be feasibly insured (Roth, 2007). The number of people protected by micro insurance globally has increased from 78 million in 2007 to 500 million as at 2013 according to a study published by the International Labour Organization and Munich Re foundation. The total market value of micro insurance is in excess of $\$ 40$ billion, according to reinsurer Swiss Re (2016), and Lloyd's of London projects that the market has the potential to someday provide up to three billion policies. The two leading micro insurance countries globally are China and India, which account for nearly $80 \%$ of the market, followed by Latin America at $15 \%$ and Africa at $5 \%$ (Timetrics, 2015). Hui, (2013) cites a report by Accenture that puts the estimated purchasing power of China's poorest at $\$ 161$ billion and India's is estimated at $\$ 93$ billion. As the purchasing power of these densely populated, low income areas continues to increase, so too does the need for insurance. The micro insurance picture in the African region epitomizes a market that is underexploited. A study by Roth et al (2005), found out that in the developing and emerging markets like Africa, only a small percentage of the population can afford conventional insurance services compared to other developed jurisdictions. A research of African micro insurance markets published by Making Finance Work For Africa (MFW4A) and Munich Re foundation (2012) found more than 44 million people were covered by micro insurance with 38 million of them concentrated in Eastern and Southern Africa, while in Central and North Africa, micro insurance remains rather limited. Insurers are increasingly making efforts to cover the African population by introducing needs-based and easy-to-understand products. Despite rising penetration of funeral insurance in South African market and mobile micro insurance services in Sub-Saharan Africa, overall micro insurance coverage is still very low in the region. According to a study by the Micro insurance Centre (2011) only $4.4 \%$ of Africans were covered by micro insurance. However, micro insurance coverage ratio for the rest of Africa, excluding South Africa, is just 1.7\% according to the same report. The African micro insurance industry has developed during the last decade, mainly due to technology and innovative delivery methods. In Kenya, study done by FSD Kenya in conjunction with the central bank of Kenya shows that the financial services sector is rapidly expanding and that the micro insurance market is still at its infancy stages (Fin Access, 2013). The Kenya policy paper on Micro insurance 2014, notes that despite piecemeal amendments that have been done to the regulations that govern insurance, challenges still persist. The current legal framework does not conform to international practices with regards to development of micro insurance as set out in the IAIS application paper on regulation and supervision supporting inclusive insurance markets. Njuguna and Arunga, (2013) also observed that the supply of commercial insurance to low income households seems to be constrained by an overly restrictive regulatory framework. The overall insurance penetration ratio in 2015 was $2.79 \%$ compared to $2.93 \%$ in 2014 . The vision for the industry is to achieve target ratio of $6.5 \%$ by year 2020 (Association of Kenya Insurers, 2016). In 2019 , only $8 \%$ reported relying on micro insurance to mitigate shocks emergencies, ( Finn Access Household Survey Report,2019).

\subsection{Objectives and Hypotheses of the Study}

The study sought to achieve the following specific objective:

I. To assess the effect of micro insurance on women empowerment

Additionally the below hypothesis was tested

Ho1: $\quad$ Micro insurance has no significant effect on women empowerment

\subsection{Significance of the Study}

This papers appends to the body of knowledge on the benefaction of micro finance institutions on empowerment of women in Kenya as reflected by any change in their living standards at individual, household or enterprise level. The results provide a framework for strategic initiatives and innovative ideas that will lead to improvement of microfinance institution's positive impact on the lives of their clientele who are mostly women. The results are also invaluable to the government for determination and establishment of a regulatory legal framework for the microfinance institutions' in Kenya, which will ensure the realization of the institutions' main objective of poverty eradication and best ways to address the gender specific issues. Additionally, the paper unveils the underlying factors that lead to economic non-sustainability of clients who already have received micro finance services yet a significant impact is not realized. 


\section{Literature Review}

\subsection{Understanding the concept of women empowerment}

A growing body of contemporary literature reports that the issue of women empowerment has become a central aspect in programs and activities of most government and nongovernmental organizations. There are varied definitions of empowerment, and methodological critique within literature with regard to the empowerment concept still persists, due to inconsistencies in its operationalization, conceptualization and measurement (Shimamoto, 2014). Nevertheless, most definitions imply some form of achievement, especially in relation to women's relative position in the household and society. Empowerment as a term has a connotation of power, and is about changing power relations to favor those who previously had limited power over their own lives. Some scholars have however argued that the empowerment idea is not related to the kind of power that dominates other people, but power to enable one to achieve goals and ends (Musonera \& Heshmati, 2016). This power enables individuals gain control over resources (physical, human, intellectual, financial and self), as well as control over ideology in terms of beliefs, values and attitudes. Empowerment can therefore be considered as a process of gaining control(Batliwala, 1993, cited in Cornwall, 2016), in this context, control of one's life. Empowerment has also been defined as a process that brings people who are outside decision-making process into it. When applied to women, it is considered important as it leads to a positive change that improves women's fall-back position and bargaining power within a patriarchal system, while creating awareness and capacity building (Rahman, 2013). Women empowerment entails change, and the ability to make choices (Kabeer, 2005), also referred to as strategic life choices. Kabeer's concept of "choices" encompasses three inter-related components that define empowerment: resources, which constitute the preconditions under which choices are made (pre-conditions of empowerment); agency (the process - which includes control of resources and decision-making), and achievements, the outcomes of choices (Malhotra et al, 2002).

(Basu, 2006) has noted that empowerment can be grouped into three types, namely: Economic empowerment: women's access to savings and credit gives them a greater economic role in decision making through their decision about savings and credit. When women control decisions regarding credit and savings, they will optimize their own and the household's welfare (Mayoux, 2000). The investment in women's economic activities will improve employment opportunities for women and thus have a 'trickle down ' effect. Increased well-being: access to savings and credit facilities and women's decision about what is being done with savings and credit strengthens women's say in economic decisions of the household. This enables women to increase expenditure on the well-being of themselves and their children. Social and political empowerment: a combination of women's increased economic activity and control over income resulting from access to micro-finance with improved women's skills, mobility, access to knowledge and support networks. Status within the community is also enhanced. These changes are reinforced by group formation, leading to wider movements for social and political change (Biswas, 2008). Women's empowerment needs occur along the following dimensions: economic, socio-cultural, familial/interpersonal, legal, political, and psychological. However, these dimensions are very broad in scope, and within each dimension, there is a range of sub domains within which women may be empowered (Mayoux, 2000).

\subsection{Micro insurance}

Micro insurance is the provision of insurance to low income individuals and small businesses. This form of insurance aims at enabling low income individuals manage risks such as accidents, death, floods, drought and poor harvest at affordable premiums. These micro insurance services tend to work better within the context of group insurance rather than individual insurance due to the cost of premiums being more affordable to the group than to the individual. In Kenya, already some insurance and non insurance institutions have welcomed micro insurance by introducing products such as Afya Bora by CIC and Salama Sure by UAP with Faulu Kenya offering Faulu Afya. Most of these products focus on primary risks such as Livestock and Crop, Health, Funeral and Life insurance. Other financial institutions facilitate the development of micro insurance through marketing, distribution as well as serving as premium collection and claims payments point. These include Banks, MFIs ,Mobile Money Transfer providers and Sacco(IRA Annual Report,2019). While the Insurance Regulatory Authority of Kenya (IRA) has been encouraging the provision of these insurance services, micro insurance provision is still limited and uptake is very low (IRA, 2014). The most common shock or risks that financially impacted most Kenyans was health related, with no major distinction between the wealth quintiles. However the impact was felt more among the poorest. However, rural households were most financially impacted by the loss of livelihoods, while urban households felt that the death of a family member impacted on their finances most. In 2019, only 8\% reported relying on micro insurance to mitigate shocks emergencies, ( Finn Access Household Survey Report,2019).

Since micro-insurance sector is relatively new, to date, a growing number of impact assessments have been conducted or are still underway regarding the effects of micro insurance on the welfare of low-income individuals. Thus, understanding the effects of micro insurance is not only important for development driven players but also market oriented actors, like insurance companies. It helps design better products, gain a competitive edge, and thus 
stimulate the market in the long term. However, because the field of micro-insurance is still new, it is not clear where to look for the impact. However, its knowledge is still patchy but certain key insights are emerging (Dercon and Kirchberger 2018). Therefore, known collectively as micro-insurance, these new financial products seek to help the poor by reducing their vulnerability to unexpected shocks like illness or death. Stefan Dercon, in his survey of income shocks suffered by individuals covered by the Ethiopian Rural Household Survey between 1999 and 2004, estimates that "if these shocks had been insured and smoothed, poverty would have been lower by about a third" (Dercon 2016). However, whether and how they actually do help the poor, however, is up for debate.

\subsection{Empowerment of women through micro insurance}

In the Kenyan market, Micro insurance products need to be accessible to the low income population particularly women. According to the Fin Access 2009, Industry consultations have revealed that there is no consistent industry or regulatory definition of micro insurance in Kenya. Several stakeholders tended to define micro insurance to be linked and potentially limited to the clients of MFIs (Microfinance Institutions) who are mostly women. This is natural as MFIs offer some of the early entry points for micro insurance but, at the same time, micro insurance can extend well beyond the MFI sector. Some players have also been hesitant to define banc assurance as micro insurance as bank clients are not perceived as "poor enough" to qualify for micro insurance.. According to the Association of Kenyan Insurers report(2018),Micro insurance was introduced in 2013 and its uptake remains very low. In 2019, only $8 \%$ reported relying on micro insurance to mitigate shocks emergencies,( Finn Access Household Survey Report,2019). There is still not enough evidence to suggest whether or not micro insurance in Kenya affects women empowerment.

\subsection{Conceptual Framework}

A conceptual framework according to Orodho (2009) is a type of a model that illustrates the nature of relationships between independent and dependent variables under investigation. This conceptual framework is build on the ground that if the MFI mission and objectives are geared towards women empowerment, then the terms, conditions and methodology and product design have to be favorable for women to access micro insurance by MFIs. As a result effects of micro insurance by MFIs on women empowerment may be expected in terms of income generation, asset building and reduced vulnerabilities defined as increases in ownership of household's physical assets and reduced vulnerabilities as the poor are encouraged to save and diversify their livelihood activities, empowerment which means enabling women to have greater control over the resources and their lives and taking part in family and community decisions, building social capital implying reduced isolation, opportunity to share information and building the bond that was not previously there. This will in turn lead to empower women and all family members. The conceptual framework in Figure1 hypothesizes the relationship between independent variables and dependent variable identified for the purpose of the study.

\section{Research methodology}

\subsection{Research Design}

Research design refers to a defined road map to achieving the study objectives and answering research questions (Stevens, Loudon \& Wrenn, 2012). Descriptive survey research design and casual effect was adopted. According to Kothari (2013), descriptive research seeks to find out what is happening or what is causing a certain occurrence. It was adopted because the aspect of survey will be based on the fact that, the study was conducted at a specific point in time , and the respondents cut across different groups. The study was "cause-and-effect" in nature and thus an explanatory cross-sectional survey research design was used which aimed at assessing the effect of micro insurance by MFIs on empowerment of women.

\subsection{Target Population}

The target population is asserted to be the entire set of units to which the findings will be generalized(Levy \& Lemeshow,2013). The target population was limited to a representative in each of the women groups operating income generating projects in Nakuru West Sub-County who have participated in microfinance. There are a total of 293 active registered women groups in Nakuru West Sub-County.

\subsection{Sampling Procedure}

Sampling procedure is the analysis of data from samples constitutes a major proportion of contemporary research. Therefore, to arrive at the sample the study employed simple random sampling due to its ease of use and accuracy of representation.

3.3.1 Sample size

Burns and Groove (2003), refer to sampling as a process of selecting a group of people, events or behavior with which to conduct a study. The study adopted a formula by Nassiuma (2000) to estimate a finite sample size, $\mathrm{n}$. 


$$
n=\frac{N C^{2}}{C^{2}+(N-1) e^{2}}
$$

Where

$\mathrm{n}=$ sample size;

$\mathrm{N}=$ population size;

$\mathrm{C}=$ coefficient of variation and $\mathrm{e}$ is error margin

Substituting these values in the equation, estimated sample size (n) is: $\mathrm{n}=293 * 0.3^{2} /\left\{0.3^{2}+(293-1) 0.02^{2}\right\}$

$\mathrm{n}=127$

Therefore the study employed simple random sampling to select 127 women representatives out of the 293 women groups.

\subsection{Data Collection}

According to Mugenda and Mugenda (2011), questionnaires are very suitable in survey research. In line with this assertion, the study adopted semi-structured questionnaire with open and closed questions to collect primary data .The questionnaire was designed and prepared on a five point Likert Scale in a manner that makes it attractive and inviting to the respondents as recommended by Mugenda \& Mugenda (2011) . Most importantly, it captured data regarding both the independent and dependent variables. The study adopted this instrument because it enables the researcher to collect both qualitative and quantitative data from the respondents.

\subsection{Validity and Reliability of Research Instruments}

The study sought to determine the content validity of the research instrument. Thus, the content validity of a measuring instrument refers to the extent to which it provides adequate coverage of the investigative question guiding the study (Cooper \& Schindler, 2014). The researcher sought the expert opinion of University supervisors to ascertain the content validity of the questionnaire. When reliability is upheld, then the research instrument should collect similar data when administered to different sampled populations exhibiting related characteristics (Mbula,2016). The study employed Cronbach alpha $(\alpha)$ coefficient to test the reliability of the research instrument. Cronbach alpha is considered to be a measure of reliability. The general rule of thumb is that a Cronbach alpha of $0.70,0.80$, and 0.90 and above is best. Cronbach alpha tests to see if multiple question Likert scale surveys are reliable. These questions measure latent variables-hidden or unobservable variables that are difficult to measure in real life.

\subsection{Data Analysis and Presentation}

Descriptive analysis involved frequencies and Chi Square test of good fit run through the SPSS software package. This analysis allowed distinct comparisons of outcomes and conclusions to be made from the findings. Inferential statistics such as Pearson Product Moment Correlation to test the overall significance of the relationship between independent and dependent variable at $95 \%$ confidence level .The analysis also sought to test the hypothesis of the study and explain the associations and dependencies between the variables.

\section{Results}

\subsection{Descriptive Findings of Micro Insurance and Women Empowerment}

It was deduced from the findings, regarding subscription of insurance schemes operating in Nakuru $84.3 \%$ of the respondents indicated very little extent, some extent was $1.1 \%$ and very great extent were $14.6 \%$. Effects of micro-insurance to enable its members to build strong trust bonds with group members, a majority of $91.0 \%$ of the respondents indicated very little extent, great extent were a total of $9 \%$. With regard to effects to enable create more social networks bonds within the community, a total majority of $81.3 \%$ indicated very little extent, some extent was $1.1 \%$, great extent were a sum of $15.7 \%$. On the effects to motivate participation in development social activities, a sum majority of $89.9 \%$ indicated very little extent, some extent was $1.1 \%$ and very great extent were $9.0 \%$. There was no disparities in the responses of the respondents and no common diverse opinions. This is seen in their $\mathrm{P}$ values as they are less than 5\%.(Table 1)

The results demonstrates a pattern that majority of the respondents have not subscribed to the micro insurance schemes provided by MFIs operating in Nakuru. Hence lesser responses were observed on the level of agreement on effects of micro insurance to building strong trust bonds, effects of micro insurance service on social network bonds within the community and effects of micro insurance service on motivation to participate in development activities. This implies that penetration of micro insurance services in Nakuru West Sub county is still low.

Women empowerment was measured in three categories namely economic empowerment, increased well being and socio political empowerment respectively. In reference to economic empowerment the study found out on whether more women have established businesses through Micro insurance, great extent were a total of $12.4 \%$, some extent were $25.8 \%$, little extent were a sum of $61.8 \%$. In line whether using Micro insurance has created 
work opportunities among other women a sum total of $21.4 \%$ of the respondents indicated great extent, some extent were $28.1 \%$, little extent were a total of $50.6 \%$. In the statements, to establish businesses through Micro insurance and creating work opportunities for other women, there was no disparities in responses by respondents, while in the statements increasing women's property possession and experiencing growth in business and increase profits, respondents showed disparity and diverse opinions in their responses. This is seen in their $\mathrm{P}$ values respectively.(Table 2)

On the above findings on increased well being through contribution to household income and household savings, great extent were a total of $30.4 \%$, some extent were $25.8 \%$, little extent were a sum total of $43.8 \%$.In regards to taking challenges and believing in own self majority of $79.8 \%$ of the respondents indicated great extent, some extent were $3.4 \%$ and little extent were $16.9 \%$. Regarding receiving respect, great extent were a total of $91.0 \%$, some extent were $6.7 \%$, little extent were total of $2.2 \%$. In respect to increase of self esteem among women who utilize Micro insurance, great extent were a sum of $19.1 \%$, some extent were $15.7 \%$ and little extent were a total of $65.2 \%$. Lastly, on increase of self confidence among women who utilize micro insurance, a total majority of $23.6 \%$ of the respondents indicated great extent, some extent were $22.5 \%$ and little extent was $53.8 \%$. Almost all responses had $\mathrm{P}$ values of less than 5\% indicating cohesion in respondents views.(Table 3).

In respect to socio political women empowerment, encouraging other women since subscribing to micro insurance, a total majority of $15.8 \%$ indicated great extent, some extent were $9.0 \%$ and little extent were a sum total of $75.3 \%$. In reference to interacting with people freely and address gatherings with ease, a majority of $71.9 \%$ of the respondents indicated great extent and some extent were $28.1 \%$. Moreover, in regards to gaining greater say when it comes to economic and other decisions, great extent were a total of $79.7 \%$ and some extent were $20.2 \%$. Lastly, on women becoming visible leaders, great extent were a total of $83.1 \%$ and some extent were $16.9 \%$. The researcher noted that there was no disparity on respondents views with $\mathrm{P}$ values being less than $5 \%$. This indicated consensus in views regarding socio political women empowerment through Micro insurance.(Table 4).

From the above findings regarding effect of micro insurance by MFIs on women empowerment, it can be concluded that, despite their very low level of agreement responses on micro insurance, women still feel empowered economically, in their well being ,socially and politically.

\subsection{Association between Micro-insurance and Women Empowerment}

The ultimate goal of this analysis was to establish relations between the two variables. Correlation coefficients measure the extent of these relations. Each such coefficient must lie between -1 and +1 , inclusive. A positive coefficient indicates a positive association whereas a negative coefficient indicates a negative association between the variables. Findings(Table 5) indicate that there is a weak positive correlation was seen between micro insurance and women empowerment which was not statistically significant $(r=.201, p=.059>0.05)$. Hence the null hypothesis Ho1: Micro insurance has no significant effect on women empowerment failed to be rejected.

\section{Summary and Conclusions}

The findings revealed that respondents did not have common diverse opinions regarding subscription of insurance schemes provided by MFIs, enabling one to build strong bonds with group members , creating more social network bonds within the community and participating in social development activities. Correlation test indicated the presence of a very weak positive insignificant relationship between micro insurance and women empowerment $(\mathrm{r}$ $=.201, \mathrm{p}=.059>0.05)$. Hence it showed that micro insurance has no significant effect on women empowerment in Nakuru CBD, West Sub County, Kenya. As micro insurance is relatively new to the literature, it was observed that there was negative effects on women empowerment. This is probably because outreach of micro insurance in Nakuru ,West Sub County is low. This is seen as $84.3 \%$ of the respondents had not subscribed to any micro insurance schemes operating in Nakuru CBD. As a result these findings create key areas of insights that would be of essence to stakeholders in the development sectors. Hence, this study indicated since majority of the respondents asserted that micro-insurance services have not been able to reach them. Therefore, penetration of these services should be able to reach them as micro insurance services are as important as the microcredit and micro-savings services for more sustainable livelihood.

\section{Recommendations}

From the conclusions, the following recommendations are made:

a) Since residing in a rural area increases participation in micro insurance by rural women borrowers, the government should establish policies that will encourage outreach of micro insurance services by MFIs to the rural population. This may be through giving incentives to providers who wish to set up MFIs in rural areas. Some of the incentives may include tax breaks, subsidies from government, preferential interest rate and infrastructural support.

b) There is also the necessity to compare the effects between different schemes and between different microfinance institution programs for example between micro-insurance and alternative risk 
management mechanisms- this is important to guide prudent investment of government and development fund.

\subsection{Suggestion for Further Research}

In presence of the findings discussed above, the following areas are recommended for further research:

a) This study also recommends further research to be done to assess effect of micro insurance by MFIs in the context of group lending instead of individual lending and compare whether they have any similarities. The practice of group lending in microfinance is an emerging issue where most microfinance institutions prefer to use in Kenya so a study under this will give insight toward policy making in development.

b) The study further suggests that similar studies should be conducted in different localities to authenticate the findings of this study and enable generalization of these findings.

\subsection{Limitations of the Study}

The study was faced by various challenges. Due to the Covid19 pandemic ,the respondents were reluctant at first as a way of precaution. However, the researcher overcame this limitation by suggesting cold calling interviews and observing health and social measures by carrying a hand sanitizer, wearing a 3 ply face mask and maintaining social distance with the respondents. There was a slow response by some respondents to complete the questionnaires administered. This was attributed by language barrier as some respondents were not conversant with English. To surmount the challenge posed, the researcher translated verbally the questionnaires into the local Swahili language. These being confidentiality and flexibility of the respondents , most women were not willing to disclose information doubting the authencity of the research. This limitation was however, overcame by showing an official NACOSTI letter and explaining to the respondents the reasons for the study. The research covered only women in Nakuru CBD, West Sub-County. Hence the study did not incorporate the respondents from other regions in the country. This was due to the limitation of time and financial resources.

\section{References}

Association of Kenya Insurers.(2016). (2015). Insurance Industry Report. Nairobi.

Barasa, K. (2016). To identify a framework for adoption by insurance industry for enhancing insurance penetration. Nairobi: Strathmore University.

Best Review. ( July 2015). Top Global Insurance Brokers.

CENFRI. (2010). Kenya Micro insurance Landscape : Market and Regulatory analysis. Bellville: CENFRI.

Churchill, C. M. (2014). Micro insurance reaches a tipping point. Best Review , 115(5).

Creswell, J. (2013). Research design : Quantitative, Qualitative and mixed methods approaches. Thousand Oaks, CA: SAGE Publications.

Cull, R. J. (2017). Microfinance and Economic Development World Bank Policy Research Working Paper 8252.

Demirgüç-Kunt, A. L. (2018). The Global Findex database 2017: Measuring Financial Inclusion and the Fintech Revolution.Overview booklet. Washington DC: World Bank.

Fin Access. (2013). Financial Access Household Survey . Nairobi: FSD Kenya.

FinAccess. (2019). Financial Acess Household Survey. Nairobi: FSD Kenya.

FINMARK TRUST \& CENFRI. (2010). Reaching the Client: Update on Micro insurance Innovation in South Africa. Bellville:FINMARK TRUST\& CENFRI.

Hui, J. (2013). The Rise of Micro insurance. In Risk management, (pp. 60(2),10,11).

IAIS. (2010). Issues paper on the Regulation and Supervisiom of Mutuals, Cooperatives and other Community Based Organisations in increasing acccess to Insurance Markets. Geneva: IAIS and Microfinance Network.

Kamau, G. M. (2013). Factors contributing to low insurance penetration in Kenya . International Journal of Social Sciences and Entrepreneurship , 1,(2),1.

Makove, S. M. (2011). African Policy Approaches: Micro insurance in Kenya. Victoria Falls, Zimbabwe: AIO Regulators Workshop.

Morelli, E. O. (2010). Micro insurance: An innovative tool for risk and disaster management. Switzerland :: Buchdruckerei Davos AG.

Mugenda.O.M.\& Mugenda, A. (2011). Research Methods: Qualitative and Quantitative approaches. Nairobi: Acts Press.

Njuguna, A. G. (2013). Risk Management Services: A survey of Micro insurance Service Providers in Kenya. International Journal of Financial Research.

Prahalad, C. K. (2010). The fortune at the bottom of the pyramid : Eradicating poverty through profits. Wharton School Publishing.

Roth, J. .. (2007). Micro insurance and Microfinance Institutions: Evidence from India.Working Group on Micro insurance ,Good and Bad practices,case study no. 15. Geneva: ILO,Social Finance Programme.

Roth, J. L. (2007). The landscape of Microinsurance in the worlds 100 poorest countries. 
Timetric. (2015). Microinsurance : tapping an uncoventional market.

Independent variable

Micro insurance

- Build strong bonds with other women

- Creating more social network bonds within the community

- Motivation participation in social development activities
Dependent variable

Indicators of women empowerment

- Increased profits

- Increased income

- Increased asset ownership

- Increased savings

- Increased employment opportunities

- Increased self esteem and confidence

- Increased leadership roles

Figure 1: Effect of Micro insurance by MFIs on Women Empowerment

Table 1: Responses on the effects of Micro insurance on women empowerment

\begin{tabular}{|l|l|l|l|l|l|l|l|}
\hline & $\begin{array}{l}\text { Very Great } \\
\text { Extent }\end{array}$ & $\begin{array}{l}\text { Great } \\
\text { Extent }\end{array}$ & $\begin{array}{l}\text { Some } \\
\text { Extent }\end{array}$ & $\begin{array}{l}\text { Little } \\
\text { Extent }\end{array}$ & $\begin{array}{l}\text { Very Little } \\
\text { Extent }\end{array}$ & $\chi^{2}$ & $\begin{array}{l}\text { P } \\
\text { value }\end{array}$ \\
\hline $\begin{array}{l}\text { To subscribe to insurance } \\
\text { schemes provided by MFIs } \\
\text { operating in Nakuru }\end{array}$ & $13(14.6)$ & 0 & $1(1.1)$ & 0 & $75(84.3)$ & 106.337 & .000 \\
\hline $\begin{array}{l}\text { To build strong bonds with } \\
\text { other women }\end{array}$ & $7(7.9)$ & $1(1.1)$ & 0 & 0 & $81(91.0)$ & 133.843 & .000 \\
\hline $\begin{array}{l}\text { To create more social network } \\
\text { bonds within the community }\end{array}$ & $13(14.6)$ & $1(1.1)$ & $1(1.1)$ & 0 & $74(83.1)$ & 164.798 & .000 \\
\hline $\begin{array}{l}\text { To motivate participation in } \\
\text { social development activities }\end{array}$ & $8(9.0)$ & 0 & $1(1.1)$ & 0 & $80(89.9)$ & 128.921 & .000 \\
\hline
\end{tabular}

Table 2: Responses on Women Economic Empowerment through Micro insurance

\begin{tabular}{|l|l|l|l|l|l|l|l|}
\hline & $\begin{array}{l}\text { Very } \\
\text { Great } \\
\text { Extent }\end{array}$ & $\begin{array}{l}\text { Great } \\
\text { Extent }\end{array}$ & $\begin{array}{l}\text { Some } \\
\text { Extent }\end{array}$ & $\begin{array}{l}\text { Little } \\
\text { Extent }\end{array}$ & $\begin{array}{l}\text { Very } \\
\text { Little } \\
\text { Extent }\end{array}$ & $\chi^{2}$ & $\begin{array}{l}\text { P } \\
\text { value }\end{array}$ \\
\hline $\begin{array}{l}\text { To establish businesses } \\
\text { through Micro insurance }\end{array}$ & $7(7.9)$ & $4(4.5)$ & $23(25.8)$ & $15(16.9)$ & $40(44.9)$ & 46.899 & .000 \\
\hline $\begin{array}{l}\text { To create work opportunities } \\
\text { for other women through } \\
\text { using Micro insurance }\end{array}$ & $8(9.0)$ & $11(12.4)$ & $25(28.1)$ & $7(7.9)$ & $38(42.7)$ & 40.382 & .000 \\
\hline $\begin{array}{l}\text { To increase women's } \\
\text { property possession through } \\
\text { using Micro insurance }\end{array}$ & $15(16.9)$ & $14(15.7)$ & $17(19.1)$ & $22(24.7)$ & $21(23.6)$ & 2.854 & .583 \\
\hline $\begin{array}{l}\text { To experience growth in } \\
\text { business and increase profits } \\
\text { through Micro insurance }\end{array}$ & $11(12.4)$ & $16(18.0)$ & $20(22.5)$ & $17(19.1)$ & $25(28.1)$ & 6.000 & .199 \\
\hline
\end{tabular}


Table 3: Responses on Increased well being through Micro insurance

\begin{tabular}{|l|l|l|l|l|l|l|l|}
\hline & $\begin{array}{l}\text { Very } \\
\text { Great } \\
\text { Extent }\end{array}$ & $\begin{array}{l}\text { Great } \\
\text { Extent }\end{array}$ & $\begin{array}{l}\text { Some } \\
\text { Extent }\end{array}$ & $\begin{array}{l}\text { Little } \\
\text { Extent }\end{array}$ & $\begin{array}{l}\text { Very } \\
\text { Little } \\
\text { Extent }\end{array}$ & $\chi^{2}$ & $\begin{array}{l}\text { P } \\
\text { value }\end{array}$ \\
\hline $\begin{array}{l}\text { Contribution to household } \\
\text { income has increased and so } \\
\text { is the household savings }\end{array}$ & $11(12.4)$ & $16(18.0)$ & $23(25.8)$ & $23(25.8)$ & $16(18.0)$ & 6.000 & .199 \\
\hline $\begin{array}{l}\text { To take challenges and } \\
\text { believe in one self }\end{array}$ & $50(56.2)$ & $21(23.6)$ & $3(3.4)$ & $15(16.9)$ & 0 & 53.697 & .000 \\
\hline $\begin{array}{l}\text { To receive respect in the } \\
\text { neighborhood }\end{array}$ & $68(76.4)$ & $13(14.6)$ & $6(6.7)$ & $1(1.1)$ & $1(1.1)$ & 182.404 & .000 \\
\hline $\begin{array}{l}\text { Self esteem has increased } \\
\text { among women who utilize } \\
\text { MFIs interventions } \\
\text { especially micro insurance }\end{array}$ & 0 & $17(19.1)$ & $14(15.7)$ & 0 & $58(65.2)$ & 40.742 & .000 \\
\hline $\begin{array}{l}\text { Self confidence has increased } \\
\text { among women }\end{array}$ & 0 & $21(23.6)$ & $20(22.5)$ & $1(1.1)$ & $47(52.8)$ & 48.124 & .000 \\
\hline
\end{tabular}

Table 4: Responses on Socio political women empowerment through Micro insurance

\begin{tabular}{|l|l|l|l|l|l|l|l|}
\hline & $\begin{array}{l}\text { Very Great } \\
\text { Extent }\end{array}$ & $\begin{array}{l}\text { Great } \\
\text { Extent }\end{array}$ & $\begin{array}{l}\text { Some } \\
\text { Extent }\end{array}$ & $\begin{array}{l}\text { Little } \\
\text { Extent }\end{array}$ & $\begin{array}{l}\text { Very Little } \\
\text { Extent }\end{array}$ & $\chi^{2}$ & $\begin{array}{l}\text { P } \\
\text { value }\end{array}$ \\
\hline $\begin{array}{l}\text { Encouraging other women } \\
\text { since subscribing to Micro } \\
\text { insurance schemes }\end{array}$ & $7(7.9)$ & $7(7.9)$ & $8(9.0)$ & $1(1.1)$ & $66(74.2)$ & 164.876 & .000 \\
\hline $\begin{array}{l}\text { Interacting with people } \\
\text { freely and address } \\
\text { gatherings with ease }\end{array}$ & $56(62.9)$ & $8(9.0)$ & $25(28.1)$ & 0 & 0 & 39.933 & .000 \\
\hline $\begin{array}{l}\text { Gaining greater say when it } \\
\text { comes to economic and } \\
\text { other decisions }\end{array}$ & $65(73.0)$ & $6(6.7)$ & $18(20.2)$ & 0 & 0 & 65.551 & .000 \\
\hline $\begin{array}{l}\text { Becoming a more visible } \\
\text { leader }\end{array}$ & $60(67.4)$ & $14(15.7)$ & $15(16.9)$ & 0 & 0 & 46.539 & .000 \\
\hline
\end{tabular}

Table 5: Correlations between Micro insurance and Empowerment of women

\begin{tabular}{|l|l|r|r|}
\hline \multicolumn{2}{|c|}{ Correlations } & insurance & women \\
\hline \multirow{3}{*}{ insurance } & Pearson Correlation & 1 & .201 \\
\cline { 2 - 4 } & Sig. (2-tailed) & & .059 \\
\cline { 2 - 4 } & $\mathrm{N}$ & 89 & 89 \\
\hline \multirow{3}{*}{ women } & Pearson Correlation & .201 & 1 \\
\cline { 2 - 4 } & Sig. (2-tailed) & .059 & 89 \\
\cline { 2 - 4 } & $\mathrm{N}$ & 89 & \\
\end{tabular}

